\title{
Alternative Urban Eco Tours for Responsible Consumption and Sustainability - the Example of Bulgaria
}

\author{
Hristina Bancheva-Preslavska ${ }^{1}$, Jochen Dallmer ${ }^{2}$
}

\begin{abstract}
The European Environment Agency warns that Europe consumes too many resources and causes environmental degradation all over the world. This leads to growing demands on natural systems for food, water and energy. To achieve sustainability and ecological resilience it is necessary to complement technology-focused measures with approaches addressing consumption behaviors, changing lifestyles, enhancing knowledge and education.

There are environmental communication approaches stimulating responsible consumption and ecofriendly behaviors, conducted by science and educational institutions, non-governmental organizations and others. Among them, originating from Germany, are the alternative city tours, spread also in other western countries.

The aim of this case study is to design and verify urban eco tours for an eastern country - Bulgaria in order to increase young people's sensitivity to sustainability through responsible consumption and to encourage them for ecofriendly alternatives of everyday goods and services. An approach for their implementation in Bulgaria is developed and proved through qualitative and quantitative analysis, involving two different groups of youth - multipliers leading the tours and teenagers taking part.

The case study presents urban eco tours as an environmental protection tool, using information about environmental impact of consumption, combined with motivational activities, to change attitudes and encourage young people for ecofriendly lifestyles.
\end{abstract}

Keywords: environmental communication, education for sustainable development, eco tour, consumption, ecology

\section{Introduction}

The assessment of global megatrends of the European Environment Agency (EEA) in 2011 warns that a larger and richer global population with expanding consumption needs would place growing demands on natural systems for food, water and energy. In its report from 2019, EEA confirms that Europe continues to consume more resources and cause more environmental degradation. Even more - European consumption creates significant environmental problems in other parts of the world. It reports the need to transform our societal systems and complement technology-focused measures with approaches addressing consumption levels and behaviors. It explains that achieving sustainability and ecological resilience requires fundamental changes in lifestyles, production and consumption, knowledge and education. Developing sustainable lifestyles has since long been identified as one of the main goals of sustainable development. (Jackson, 2008). Education has been recognized as one main pillar of promoting sustainable development within societies. 
The concept of Education for Sustainable Development (ESD) has been developed to spread information, create awareness and most of all teach competences that people need to make responsible choices regarding their own lifestyles as well as their partaking in society (UNESCO, 2012, 2017). The issue of responsible consumption has been one key topic of ESD, especially in western societies with their high level and big social importance of consumption. Information and training on sustainable consumption cover most of the UN Sustainable Development Goals (UN, 2015), incl. the literal responsible consumption and production, but also aspects of all other goals (no poverty, good health and well-being, clean water and energy, industry, innovation, sustainable cities, life on land, etc.). While responsible consumption can be criticized for its unfulfilled promises regarding the de facto environmental impact (Grunwald, 2012), education about responsible consumption as it is pursued in Education for Sustainable Development has a profound educational approach. Learners are not being taught how to consume responsibly, but are invited and motivated to deal with the implied issues of globalized consumption. They learn to look at topics from different perspectives, to balance conflicting arguments about consumption and to develop their own informed position and their daily choices as consumer and citizen (Dallmer, 2012).

Germany has been one of the leading countries in implementing ESD in the educational sector, during the UN decade, almost 2000 projects have been certified as good practice examples (Deutsche UNESCO-Kommission, 2015). Many of the projects dealt with the topic of sustainable consumption. In the project $B i N K$, three German universities and one research institution in a cooperation with a couple of schools develop solutions of the question how educational institutions can become places where sustainable consumption could be learned and actively cultivated. Consumer Classroom is an initiative of the European Commission for teachers. Its website contains a library on consumer education from across the EU and provides interactive and collaborative tools to help prepare and share lessons. KonsumKompass of The German Federal Environmental Foundation (DBU) is an exhibition which has been touring through Germany and is also available online about the origin of products, explaining which raw materials are used and who makes them under what conditions. Most of the used environmental communication approaches (Flor, 2004) and initiatives stimulating responsible consumption, environmental awareness and ecofriendly lifestyle are classroom/indoor based, while city tours use urban environment and side-specific methodology.

The concept of educational guided city tours for sustainability starts more than 15 years ago as an idea by young volunteers, to make the social and ecological effects of globalized production chains more visible in daily consumption. The idea developed into a successful approach and spread throughout Germany under the succeeding projects named KonsuMensch, KonsumGlobal and WELTbewusst. Between 2006-2012 hundreds of city tours with thousands of participants took place in about 50 cities in Germany. The projects received various awards as 'good practice project' for ESD. The concept has also been adopted in Austria, Switzerland, Italy, the Netherlands, Sweden, and France. In 2015-2016 it is adapted for the first time for an Eastern European country - Bulgaria, through the project ConsumpThink of EcoCentric Foundation. 
The aim of this case study is to design and verify urban eco tours in Bulgaria in order to increase young people's sensitivity to sustainability through responsible consumption and to encourage them for ecofriendly alternatives of everyday goods and services.

The object of the study is the approach of the alternative urban eco tours for responsible consumption, including their content, methodology, participants and guides.

We also look on the possibility to easily transfer the project approach despite the difference in economic status and level of acceptance for non-formal educational activities between Germany and Bulgaria.

The approach for their implementation in Bulgaria is developed and proved through qualitative and quantitative analysis.

\section{Content and Methods of the Educational Tours}

The city tours are based on the following methodological approaches: "peer-to-peer education", experiential learning, interactivity, linkage to known reality, inviting critical thinking, provoking discussions, inter- and trans-disciplinarity, discovering contradictions, presenting alternatives (positive examples) and being able to take personal responsibility. Abundant visual materials are applied within the interactive, involving and motivational methods of the tour. It is based on the German framework (Dallmer \& Dieckmann, 2012), outlined below.

Table 1. German framework of alternative city tours for sustainability.

\begin{tabular}{|c|c|c|c|}
\hline Aims \& Obj & Concept & Methodology & City tour facts \\
\hline $\begin{array}{l}\text { - } \\
\text { at hand } \\
\text { - } \quad \text { Globalization } \\
\text { and consumption } \\
\text { - } \quad \text { City tour } \\
\text { - } \quad \text { Peer-to-peer } \\
\text { education } \\
\text { - Transferable } \\
\text { method }\end{array}$ & $\begin{array}{l}\bullet \quad \text { Giving } \\
\text { information } \\
\bullet \quad \text { Background } \\
\text { and critique } \\
\text { - Making } \\
\text { people think } \\
\text { alternatives, possible } \\
\text { actions (Change in } \\
\text { behing } \\
\text { behavior) }\end{array}$ & $\begin{array}{l}\text { - Interactive } \\
\text { - } \quad \text { "Fun" and } \\
\text { experience } \\
\text { - Youth } \\
\text { relevant topics/items } \\
\text { - Inviting } \\
\text { discussion } \\
\text { - Accepting } \\
\text { ambiguity }\end{array}$ & $\begin{array}{l}90 \text { minutes } \\
\text { 4-6 stops/topics } \\
\text { 10-20 participants } \\
2 \text { people/guides } \\
\text { Target groups: Youth } \\
\text { age 14+, students, } \\
\text { adults, elderly, } \\
\text { (teachers } \\
\text { present) were }\end{array}$ \\
\hline
\end{tabular}

The tour has an average duration of 90 minutes and usually includes 3-5 complementary stops that broaden and deepen the content. It is conducted in an urban environment, similar to a normal guided city tour, but instead of cultural and historical sights, the group stops in front of shops or businesses and learns about environmental and social impacts of goods and services being offered in the respective shop. The format of the city tour uses the bonus of a side-specific learning experience, being in front of the shops where the respective consumption takes place. The format of city tours allows a genuine experiential learning setting (Emde, 2020).

The stops (topics) relate to everyday products such as coffee, chocolate, clothes, shoes, meat, etc. After a short introduction to the respective topic of a stop, a mix of games and 
simulations, supported with visual material, makes participants learn about the interrelationships and interactions between humans and the environment in the production and consumption of each product group. The shops are chosen according to their location and they always represent the product type offered - the respective brand or company is not in main focus.

For example, for the topic Coffee the group stops in front of a Café or coffee shop. It deals with coffee cultivation and its environmental impacts, coffee processing waste, use of pesticides, deforestation, shady and sunny plantations. It focuses on the biodiversity importance for sustainability and the role big coffee plantations play. The alternatives introduced and discussed are various types of certified coffee - bio, Bird Friendly, Fairtrade, Rainforest Alliance, UTZ and other labels, but also local and healthy drink replacements. The topic Meat presents the industrialization of livestock breeding, the growth of meat consumption and related deforestation due to forage, overgrazing, loss of biodiversity, greenhouse gases, water footprint, GMO soy, food waste. As alternatives, the topic includes local production and reducing meat consumption. Food Waste is another complementary topic that reveals the size and relative part of food waste, its environmental, economic and social dimensions, the amounts and morphology of food waste in Bulgaria and worldwide. It focuses on the reasons for the loss and disposal of food and options for solving the problem. The alternatives offer practical ideas for food storage, purchase planning, composting and food sharing initiatives. The topic Clothing presents cotton growing - pesticides and GMOs, cotton in the food chain, environmental problems in other textiles and the stages in the clothes production. Shoes makes known the natural and artificial materials in the footwear industry, the assembly process, waste of resources. All topics include also the social element of child labor, unfair and below the poverty line payments of workers in countries of the global south. The alternatives stimulate the choice of natural materials, local production and responsible brands.

The stops complement each other with information about the local and global impact of humans' average consumption. Each stop presents global consumption problems and offers various individual solutions that each tour participant can use to reduce their global footprint. Therefore, each stop ends with discussion on the available consumption alternatives and motivates participants to make responsible consumer choices.

The tours are usually guided by two young people who have been trained for this task within the respective eco-tour project and act as volunteers. These are the multipliers. They guide the tour presenting the information objectively and impartially, through the prism of environmental, social and economic aspects of consumption, and do not allow propaganda and agitation of any kind. They use an interdisciplinary approach and encourage unconventional, creative, open, associative thinking of participants, expressing personal opinions and stimulating their critical thinking. They multiply their theoretical and practical knowledge and skills in responsible consumption among tour participants. The fact that it is not teachers or professional adult educators who run the tours contributes to their specific character and provides for the peer-to-peer approach. The response of the participants and the discussions amongst them also provide meaningful feedback on the activities outcome and eventually necessary further developments of the tour. The target group of participants are teenagers aged 14+ years. Tours are less 
suitable for younger teens and children, because of the specificity and complexity of the matter. Tours are mainly carried out with school classes during an excursion.

The tours' learning objective corresponds to the education for sustainable development objective, namely - building such skills in people that allow them, with a view to the future, to take an active part in the processes of change in society, as well as to manage these processes (Michelsen, 2009). The tours' educational approach is based on the concept of 'shaping competences' of de Haan (2008), consisting of twelve action oriented sub competences, assigned to personal, practical, social and specialized skills for shaping a sustainable future. Tours aim to make participants understand the dimensions of social and environmental problems in the production and consumption of specific goods and motivate them to take alternative solutions that prevent or reduce related environmental and social impacts. The educational activities build interdisciplinary knowledge, integrative understanding, attitude on global environmental issues related to consumption and motivate for responsible consumer choice.

A framework using reflective approach is developed to assist the multipliers in the self evaluation of conducted tours and improvement of future activities. It includes reflection on the timing of the tour, thematic logic in stops' selection, choice of tour route, guiding style and group control. Conclusions on positive and negative effects and possibilities for future improvement are also incorporated.

\section{Implementation in Bulgaria}

Starting the tours in Bulgaria began by disassembling the prototype of the German tours and rephrasing each stop with the necessary locally detailed content, checking the interactive methods for running it and developing numerous advices for tour guiding. This has been done by a team of local educators and volunteers who then also tested the first versions of the tours by free tours given to participants from the general public. After the verification all information given and the successful testing of the tours, the practical information is packed in a handbook for multipliers (BanchevaPreslavska et al., 2016). The Bulgarian approach of urban eco tours featured two adaptations of the German concept, focusing on the environmental aspects and introducing the indoor version of the tours.

The Bulgarian approach of alternative urban eco tours is more environmentally oriented, because of the interest and the attitudes of the audience. It is more understandable for Bulgarian youth to talk about global impacts through the prism of ecology and environmental protection than using the general term 'globalization' as it is done by the German tours.

Main topic of the urban eco tours in Bulgaria is the local and global environmental and socio-economic impact of everyday products' consumption and the alternatives for achieving sustainability, especially affordable alternatives. As Bulgarians have a lower disposable income, shopping is a popular leisure activity among teenagers, but not as extremely exercised as in Germany. Even more, people in Bulgaria perceive their own economic status as low compared to other European countries and are more difficult to convince to environmental/social friendly, but more expensive alternatives. Generally, most of the Bulgarians still consider the market economy a bad thing for the country 
(Bui-Wrzosińska, 2019) and are usually skeptical to 'bio', 'fair trade', certificates, as they do not really trust institutions, government, non-governmental organizations, media (Stoychev et al., 2018). In other words, they are commonly too sensitive about socioeconomical topics and the environmental educational approach predisposes participants in Bulgaria better.

The tours in Bulgaria are also adapted for indoor implementation, i.e. school campus or covered public market, where a short walk is possible and respective stops are available. Especially the indoor tour version for schools was necessary in Bulgaria, because for many schools it is difficult to do out-of-campus activities like a guided city tour due to administrative reasons. Tour stops in schools are for example the canteen, café machine, waste bins and other points that make the relation to the relevant consumption topics and (out of) school life. The movement between stops, even in the school hallways allows the same non-formal methods, used in the tours.

During 8 multiplier training courses, a total of 52 young adults between 18 and 35 years old were prepared to guide urban eco tours. From these potential multipliers, only 14 people are active for more than a year, because many are interested only in the topics of environment, consumption and sustainability, but not so much in the educational part of guiding tours. The high demand in time and preparation is also a reason for some participants of the multipliers training to remain inactive. The active multipliers are volunteers and joined the initiative aware of and convinced in its purpose and significance, therefore showing a very high level of motivation. Their reflection on conducted tours reveals the need for regular practice with groups, updating of information about consumption and improving presentation skills. Based on this, for their motivation and continuous qualification are carried out workshops, networking seminars and events, where consumption-related topics are deepened, presentation and moderation skills are developed and experiences for mutual support are shared.

In 2015-2016, 25 urban eco tours are conducted outdoor in Sofia, Blagoevgrad, Lovech, Vratsa, Mezdra and Plovdiv with a total of 303 students. In addition, there are indoor school tours, which include a total of 283 students from Sofia, Vratsa, Mezdra and Plovdiv. Thus, the verification involves a total of 40 eco tours with 586 high school students from 6 Bulgarian cities, carried out by 14 active voluntary multipliers.

\section{Results and Discussion}

A questionnaire of 5 content and 2 sociometric questions for students had been developed to evaluate the tours.

A total of 535 questionnaires of tours' participants are filled out and evaluated. About $57 \%$ of the respondents are female and $43 \%$ male with an average age of 16.7 years.

For $88.6 \%$ of the respondents it is interesting to participate in the urban eco tour and $86.7 \%$ of them would recommend it to friends. $92.1 \%$ of respondents get a lot of new information on sustainability, incl. environmental impact of consumption, alternatives for reducing the individual footprint. The urban eco tour approach helps for easier perception of information according to $88 \%$ of the respondents. Nevertheless only $61.7 \%$ of them are motivated for consumption that is more responsible, $17.8 \%$ are partly 
motivated and the rest of about $20 \%$ are not motivated at all. The results are summarized in the following figure.

0\% 10\% 20\% 30\% 40\% 50\% 60\% 70\% 80\% $90 \% 100 \%$

Was it interesting for you to participate in the alternative urban eco tour?

Would you recommend the alternative urban eco tour to your friends?

Did you get a lot of new information on sustainability?

Did the urban eco tour approach help you learn a lot about sustainability?

Did your participation in the tour motivated you to be a more responsible.

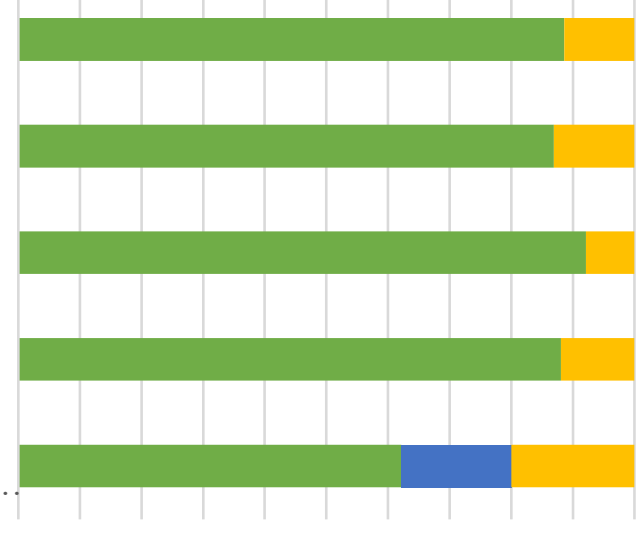

- Yes Partly $\square$ No

Figure 1. Answers of participants in the alternative urban eco tours in percentage

The verification of the urban eco tours shows that they generally contribute to a more ecofriendly lifestyle in Bulgaria through introducing responsible consumption, using 'tours' as a non-formal educational approach run by young people for young people.

They build awareness of the social, environmental and economic consequences of consumption and encourage participants to build sustainable consumer behavior and awareness of sustainability. They motivate young people to be active, developing critical thinking, allowing students to make mistakes, make conclusions and environmental decisions. They help participants to upgrade their information on consumption impacts, increase social competence and create awareness of interdependence. They foster practical project activities on sustainable consumption of food and clothing to eco-clubs from participating schools.

Most of involved schools are motivated by the project and implement their own practice-oriented projects, which achieve environmental relief effects. Some of them are: exchange of used books, CDs and DVDs, waste prevention initiative, exchange of used clothes, jacket collection campaign for donation of an orphanage, food initiative for direct delivery from farmers, upcycling - art restoration of old clothes, etc.

The alternative urban eco tours have double-level environmental awareness effect involving young people guiding other young people. For the multipliers, the participation in the initiative of urban eco tours included receiving a training, running guided tours and updating of information and methodology. This could be seen as learning in various regards and acquiring a specific qualification as multiplier. For the participants of the tours, a learning and motivational effect towards environmental protection is observed. 
Food with its broad environmental and social aspects resulted the most interesting topic for youth, especially food biodiversity and sovereignty. Food is a primary need what makes it a universal topic that affects all kind of participants and the most average form of consumption. Furthermore, there is already a popular movement like farmers' markets in Bulgaria which are welcomed and are growing, so alternatives are emerging and already en vogue. In addition, there is general awareness that Bulgaria used to be an exporting country for food items, but now it imports most of the food, as there was significantly reduction in the count of farm animals after the 1990 and severe decline in Bulgarian crop farming in the post-accession period (Dimitrova et al., 2015). This is how the idea of more regional and ecofriendly production and local markets goes along with economic aspects, what makes the topic easily understandable and acceptable for Bulgarians. Thus, since 2019, the EcoCentric Foundation's initiative focused entirely on food, nutritional biodiversity and sustainability, using a new environmental communication methodology (Bancheva-Preslavska, 2019).

\section{Conclusions}

The case study presents urban eco tours as an environmental protection tool, using information about consumption, combined with motivational activities, to encourage young people for ecofriendly lifestyles.

Urban eco tours stimulate students' responsible attitude to the surrounding world, to society and nature. They promote environmental thinking, civic engagement, and social entrepreneurship and generally develop sustainable behaviors to the environment.

The transfer of the concept from Germany to Bulgaria has been successful and needed only few adaptations. This shows the general functionality of an approach based on the principles of ESD.

\section{Acknowledgements}

The design and verification of urban eco tours was conducted within the project ConsumpThink „KonsUmdenken - Umweltbildung zum Themenfeld nachhaltiger Konsum fur Jugendliche in Bulgarien" of EcoCentric Foundation, funded by the German Federal Environmental Foundation (Deutsche Bundesstiftung Umwelt - DBU). The present study was initiated and implemented with the support of the National Science Program „Young Scientists and Postdoctoral Students“. We express our gratitude for the concern for the young researchers, scientists and professors of Bulgaria.

\section{References}

Bancheva-Preslavska, H. (2019). Food Biodiversity and Sustainability through new Methodological Approaches for Environmental Communication. KNOWLEDGE International Journal, Vol.35.3, 895-900

Bancheva-Preslavska, H., Dimitrova, A., Topchieva, M., Nenov, A., Petrova, Zh., Dzhidzhova, M., Todorov, T., Pyrvanova, D., Krumova, L., Vylcheva, T., Georgiev, M., Hristova, D. (2016). ConsumpThink city tours for responsible consumption. Handbook of the multiplier. Sofia: Ecocentric Foundation 
BINK. Educational Institutions and Sustainable Consumption. (2008-2012). Leuphana University of Lüneburg (Institute for Environmental \& Sustainability Communication), Humboldt University Berlin, German Youth Institute Munich, and University of Applied Science Fresenius. Retrieved from http://konsumkultur.de

Bui-Wrzosińska, L. (2019). States of Change. Attitudes in East and Central Europe 30 Years after the Fall of the Berlin Wall. Open Society Foundations

Consumer Classroom. (2013-2019). European Commission. Retrieved from http://www.consumerclassroom.eu

ConsumpThink. KonsUmdenken - Umweltbildung zum Themenfeld nachhaltiger Konsum fuer Jugendliche in Bulgarien. (2015-2020). EcoCentric Foundation. Retrieved from http://konsumuvai.org/bg

Dallmer, J. (2012). Konsum als Lernfeld. Zum Beispiel bei kritischen Stadtrundgängen. Hessische Jugend, $01 / 12,14-15$

Dallmer, J., Dieckmann, J. (2012). WELTbewusst Methodenset. Handreichung für MultiplikatorInnen. Berlin, BUNDjugend e.V.

de Haan, G. (2008). Gestaltungskompetenz als Kompetenzkonzept der Bildung für nachhaltige Entwicklung. - In: Bormann I., de Haan G. (Hrsg.): Kompetenzen der Bildung für nacbhaltige Entwicklung. Operationalisierung, Messung, Rahmenbedingungen, Befunde. Wiesbaden, pp. 23-43

Deutsche UNESCO-Kommission. (2015). UN-Dekade mit Wirkung - 10 Jahre "Bildung für nachhaltige Entwicklung" in Deutschland

Dimitrova, D., Ivanova, T., Chervenkov, M., Bosseva, Y., Rumiz, M. (2015). Regional Approach to Preservation of Food Related Biodiversity. Trakia Journal of Sciences, Vol. 13, Suppl. 1, 340-347.

EEA. (2011). The European environment - state and outlook. 2010: assessment of global megatrends. Copenhagen: European Environment Agency

EEA. (2019). The European environment - state and outlook. 2020. Knowledge for transition to a sustainable Europe. Luxembourg: Publications Office of the European Union

Emde, O. (2020). Lernorte des Politischen - Stadtrundgänge als außerschulische Lernarrangements einer kritisch-emanzipatorischen politischen Bildung. In: Stein, Martin/Jungwirth, Martin/Harsch, Nina/Korflür, Yvonne (Hrsg.). Forschen. Lernen. Lebren an öffentlichen Orten - The wider view. Tagungsband. Münster: WTM-Verlag.

Flor, A. (2004). Principles, Approaches and Strategies of Communication Applied to Environmental Management. Philippines: UP Open University

Grunwald, A. (2012). Ende einer Illusion: Warum oekologisch korrekter Konsum die Welt nicht retten kann. München: Oekom

Jackson, T. (2008). The Challenge of Sustainable Lifestyles. Worldwatch Institute: State of the World 2008.

KonsumKompass. (2013-2020). German Federal Environmental Foundation (DBU). Retrieved from https://www.konsumkompass.com/

Michelsen, G. (2009). Kompetenzen und Bildung für nachhaltige Entwicklung. In: Overwien, B., Rathenow, H.F. (Hrsg.). Globalisierung fordert politische Bildung: Politisches Lernen im globalen Kontext, S. 75-86. Opladen: Farmington Hills

Stoychev, G, Ivanova, I., Belcheva, D., Braynova, P., Dimitrova, R. (2018). Democracy and Civic Participation. Public Attitudes towards Democracy, the Rule of Law and Fundamental Human Rights in 2018. Open Society Institute - Sofia

UNESCO. (2012). Education for Sustainable Development. Sourcebook. Paris: United Nations Educational, Scientific and Cultural Organization

UNESCO. (2017). Education for Sustainable Development Goals - Learning Objectives. Paris: United Nations Educational, Scientific and Cultural Organization

United Nations. (2015). Sustainable Development Goals. Knowledge Platform. Retrieved from https://sustainabledevelopment.un.org

WELTbewusst. (2010-2020). Jugend im Bund für Umwelt und Naturschutz Deutschland (BUNDjugend).

Retrieved from http://www.weltbewusst.org

Young Friends of the Earth Germany). Retrieved from http://www.weltbewusst.org 